\title{
Regional Design Storm and Flood Modelling-Risk Implications in Ungauged Catchments
}

\author{
Berhanu F. Alemaw, Ron T. Chaoka \\ Department of Geology, University of Botswana, Gaborone, Botswana \\ Email: alemaw@mopipi.ub.bw, bfalemaw@gmail.com,chaokatr@mopipi.ub.bw
}

How to cite this paper: Alemaw, B.F. and Chaoka, R.T. (2016) Regional Design Storm and Flood Modelling-Risk Implications in Ungauged Catchments. Journal of Water Resource and Protection, 8, 1211-1221. http://dx.doi.org/10.4236/jwarp.2016.813093

Received: September 9, 2016

Accepted: November 25, 2016

Published: November 28, 2016

Copyright $\odot 2016$ by authors and Scientific Research Publishing Inc. This work is licensed under the Creative Commons Attribution International License (CC BY 4.0).

http://creativecommons.org/licenses/by/4.0/

\begin{abstract}
Most planned developments in a catchment for control of excess water using a culvert, bridge or dam spillway are located at a site in a stream where there are no discharge measurements. Even though, for gauged catchments a number of established flood frequency models and rainfall-runoff models do exist, for ungauged catchments mostly regional flood frequency and event-based rainfall-runoff models are used, which depend on regional parameters. In this paper, a regional approach for design floods is presented and risk implication for design of drainage structures assessed. A case study in light of the above has been considered at four ungauged sites in the Limpopo Drainage Basin in north-eastern Botswana.
\end{abstract}

\section{Keywords}

Ungauged Catchments, Drainage Structures, Dams, Design Flood, Risk Assessment

\section{Introduction}

In the design of drainage structures, hydrological modelling, flood risk assessment and flood plain management design flood estimation are essential elements. Estimation of design flood for a catchment ideally requires sufficiently long period of flood data. Because of the limitations of at-site flow data, rainfall-based flood estimation methods are often preferred by the hydrologists [1].

The input in the application of rainfall-based flood estimation methods is the expected rainfall intensity for given storm duration and return period, usually known as design storms. Design storm values are needed in many hydrological studies, especially for providing an indirect estimation of the design flood. To this end, intensity-duration-frequency (IDF) curves are often employed. These curves allow one to estimate the 
design storm, provided that historical rainfall extremes are available using scaling and stochastic models [2] [3] [4]. When observed at-site rainfall data are lacking, the estimation of the design storm may be conducted by using regional frequency analyses for infrastructure design [5] [6] [7]. Intensity-duration-frequency (IDF) models have been tested for their application in infrastructure design as well as for climate projections under non-stationary condition as a result of climate change [8] [9].

Even though, there is a network of autographic rain gauges in Botswana, their spatial distribution as well as at-site records is so short that they merit low credit for extrapolation to any ungauged sites. Most rain gauge records in Botswana have records of daily time interval that one may apply stochastic modeling of extreme daily rainfall series only. There is a limitation with the use of such data in the estimation of flush floods, which would last less than 24 hours. A limited study is carried out that indicated that much of rainfall in Botswana occurs in short spells of high intensity and occasionally very high intensities in short time periods [10]. Although no figures were given for major towns and cities in Botswana, intensity as high as $40 \mathrm{~mm}$ in a 15 -minute storm has been observed in Botswana at Gaborone on 22 Nov. 1982. Some exceptionally high intensity rainfalls recorded at Gaborone, Francistown and Maun were the basis for developing rainfall IDF curves [11].

Discharge gauging stations for a site of interest may be absent or usually sited far from locations where drainage facilities are needed. Rainfall runoff models are employed to determine design discharges from rainfall intensities of given duration and return period. Developing a unified model for derivation of IDF curves at a national scale remains vital. Otherwise, it is likely to introduce inconsistencies and significant bias in flood estimates for a given location, due to subjective treatment of the rainfall intensity and depth which is a major flood producing variable, leading to under- or over-design of engineering structures that include culverts, bridges, spillways or any flood control structures.

In this study we employ a regional flood estimation approach which relies on a regional parametric Intensity-Duration-Frequency (IDF) model developed for Botswana. The latter is a regional model for intensity-duration-frequency relationship for the estimation of rainfall extremes. It is derived by employing existing data, which is in use in Botswana by the Roads Department. The proposed formulation allows one to estimate the expected rainfall depth for a duration ranging from 5 minutes to 2 hours and beyond, and for low and medium return periods (up to 50 years) in any location in the country.

The proposed storm IDF model uses only annual rainfall data as an input. The use of the annual rainfall data, which is a measure of aridity in Botswana, is fairly reliable available information and its long-term distribution spatially in most regions over Botswana is fairly known, as documented in [12]. Furthermore, we demonstrate the regional application of the model in flood forecasting in ungauged catchments in the Limpopo Drainage Basin in the north-eastern Botswana, and we assess the risk implied by the use of the proposed regional storm and flood modeling approach. 


\section{Methodology}

In the determination of design discharge, the transformation of rainfall to runoff is undertaken through hydrological models which use rainfall as a short time event storm inputs (from seconds to hours) and/or rainfall magnitudes that occur in days, weeks, months or beyond. The former commonly known as Design Event Approach is considered to determine design discharges. Design Event Approach for estimation of design floods is the currently practiced technique in different parts of the world [13]. This approach considers the probabilistic nature of the rainfall depth, while representative or median values of other parameters like rainfall duration; temporal pattern and area are used. This obviously simplifies the procedure and makes it attractive to the practicing hydrologists. We applied this technique in simulating flood quantities in the design of bridges located at 3 ungauged catchments in Botswana.

Event-based simulations are applied to transform storm rainfalls to design discharges by using rainfall-runoff models. IDF curves/equations are used in a number of deterministic models to compute flood peaks, flood volumes, timing, etc. Examples of the currently widely used and available event-based and continuous rainfall runoff models are: i) the Rational method [14]; ii) SCS CN method [15]; iii) the HEC-1 model [16]; iv) the SHE model (Syste'me Hydrologique Europe'en model) [17]; and v) SWMM Stormwater management model [18]. Almost in all event-based models, the rainfall depths and intensity corresponding to the time of concentration of flow from a watershed draining across a point of consideration is usually considered one of the most important design parameters. The storm duration is considered a variable that equals at least the time of concentration. The latter is a morphological variable, which depends on catchment characteristics and the longest distance and time of travel for the excess rainfall to contribute the flood flow from the catchment. A detailed account of rainfall-runoff models is available in [19].

The first rainfall-runoff model we considered for evaluation of the risk associated with the regional design storm and flood modeling is the Soil Conservation Society (SCS) Curve Number (CN) method [15]. This method is widely used with apple reference available from several literatures.

The second regional approach we used was the empirical deterministic method developed by Midgley and Pitman [20]. This is a peak discharge formulae for return periods less than or equal to 100 years for drainage basins in South Africa. We consider this method because parameters for the Limpopo drainage basin are available [20], where the study catchments in this paper belong. The method is useful for rural catchments larger than $100 \mathrm{~km}^{2}$ is based on the following formula:

$$
Q_{T}=K_{T} A^{0.5}
$$

in which $Q_{T}$ is the $T$-year flood peak of catchment exit at the bridge site (in $\mathrm{m}^{3} / \mathrm{s}$ ) from a drainage area, $A\left(\right.$ in $\left.\mathrm{km}^{2}\right)$. The parameter $K_{T}$ is a constant for $T$-year return period for which flood probability charts are available.

The hydrologic risk involved in a design flood magnitude corresponding to return period $T$ is usually defied as the probability that the estimated flood will be exceeded at 
least once during the design life $(N)$ in years of the structure and it is given by:

$$
P=1-\left(1-\frac{1}{T}\right)^{N} \text {. }
$$

Equation (2) can be easily used to determine the risk, $P$ for any design if the recurrence interval $(T)$ associated with the design flood is known, along with the proposed design life of the structure. Due to the difficulty to determine the recurrence interval $(T)$ from the flood formulas, we determined it indirectly from the return period of the design storm as a function of Extreme Value Type 1 Distribution (EV1):

$$
\begin{gathered}
T=[1-\exp \{-\exp (-y)\}]^{-1} \\
y=\frac{x-u}{\alpha}
\end{gathered}
$$

where $u$ and $\alpha$ are the parameters of EV1 distribution and $y$ is EV1 reduced variate and $x$ is the design storm intensity (i) for given duration and return period.

For this purpose $x$ was determined by employing an empirical storm IDF model [21], which relates intensity and duration for any recurrence interval. A detailed account of this storm IDF model is provided in [21], but highlights are provided as follows. The model is based on a simple relationship, which has the following form:

$$
i=\frac{a \log T R+b}{t_{d}+c}
$$

in which $R$ is the mean annual rainfall (mm/a); $i$ is average rainfall intensity $(\mathrm{mm} / \mathrm{hr}) ; t_{d}$ is storm duration, time of concentration (minutes); $T$ is return period (years); and $a, b$, $c$ are constants that depend on the units employed.

In the scientific literature, the one used by the Texas Department of Transportation which is based on an exponential type formula for approximating the intensity-duration-frequency curve is commonly used. This is a formula for synthetic hyetograph known as the Chicago method. It is based on the parameters of an assumed relationship of Intensity-Duration-Frequency (IDF), for a given return period, having the following form:

$$
i=\frac{a}{\left(t_{d}+b\right)^{c}}
$$

where $i$ is average rainfall intensity $\left(\mathrm{mm} / \mathrm{hr}\right.$ or inch/hr); $t_{d}=$ storm duration (minutes); and $a, b, c$ are constants dependent on the units employed and the return period of the storm event. When Equation (6) was applied to storm characteristics in Botswana, it was found to be inferior to the storm IDF model of form given Equation (5) [21]. The data used in testing the application of the two models in [21] was the digitized rainfall intensities from [11] shown in Table 1.

Furthermore, one difficulty of the model based on Equation (6) is that is applicable for a given return period which requires three parameter sets derived separately for each return period. Whereas, the former is a parsimonious model in that it is used for any return period, $\mathrm{n}$ which is a parameter in built with the model, which requires to 
Table 1. Digitized rainfall intensities for Francistown station from BRDM charts [21].

\begin{tabular}{cccccc}
\hline & \multicolumn{5}{c}{ Return period (years) } \\
\cline { 2 - 6 } Duration (minutes) & 5 & 10 & 25 & 50 & 100 \\
\hline 5 & 123 & 155 & 180 & 213 & 269 \\
10 & 102 & 130 & 150 & 177 & 224 \\
20 & 77 & 97 & 113 & 133 & 168 \\
30 & 61 & 78 & 90 & 106 & 134 \\
60 & 38 & 49 & 56 & 66 & 84 \\
90 & 28 & 35 & 41 & 48 & 61 \\
100 & 26 & 32 & 38 & 44 & 56 \\
\hline
\end{tabular}

optimize only the 3 parameters $(a, b, c)$ for any $n$. Whereas, the advantage of the first model proposed in this study, Equation (5), is versatile and robust and parsimonious. The only optimized model parameters are $a, b$ and $c$, (Table 2) which are parameters of the proposed IDF model for the given storm durations and various return periods, defined by the parameter $T$, for any region of given $R$.

The methodology adopted in this study is based on parameter optimization of the above empirical formulation (Equation (5)) using the observed record of rainfall IDF. Finally a test of the models was performed to examine their applicability in reproducing the observed intensities qualitatively and quantitatively for the various return periods and durations. The design storms are inputs used in the event-based rainfall-runoff modeling approach to estimate design flood quantities, and risks associated with the use of the flood estimates in the design of drainage structures.

\section{Data Used}

The observed record of rainfall IDF data is available as charts from the Roads Design Manual [11] used by the Roads Department. The representative design storm charts are available for Gaborone, Francistown and Maun. We have digitized the storm intensity data for the durations of $5,10,20, \ldots, 120$ minutes and return periods of $5,10,25$ and 50 years.

For Francistown station, which is close to the study catchments, the data digitized and used in the study to illustrate the applicability of the design storm model, for selected durations and return periods is summarized in Table 1.

We have considered four ungauged catchments which are tributaries to the Limpopo drainage basin (Figure 1). These are:

- Nyamambisi River Crossing Marobela-Sebina Road (Nyamambisi).

- Gatswane River located at a road crossing along Tshesebe-Butale road (Gatswane 1).

- Gatswane River in the downstream side along Butale-Senyawe (Gatswane 2).

- Shashe River at Kalakamate along the Msiwizi-Kalakamate road (Shashe).

The characteristics of the four catchments considered including their catchment area $(A)$, length $(L)$, slope $(S)$, time of concentration were determined based on the Kirpich's formula $(T c)$ and mean annual precipitation $(R)$ are summarized in Table 2. 


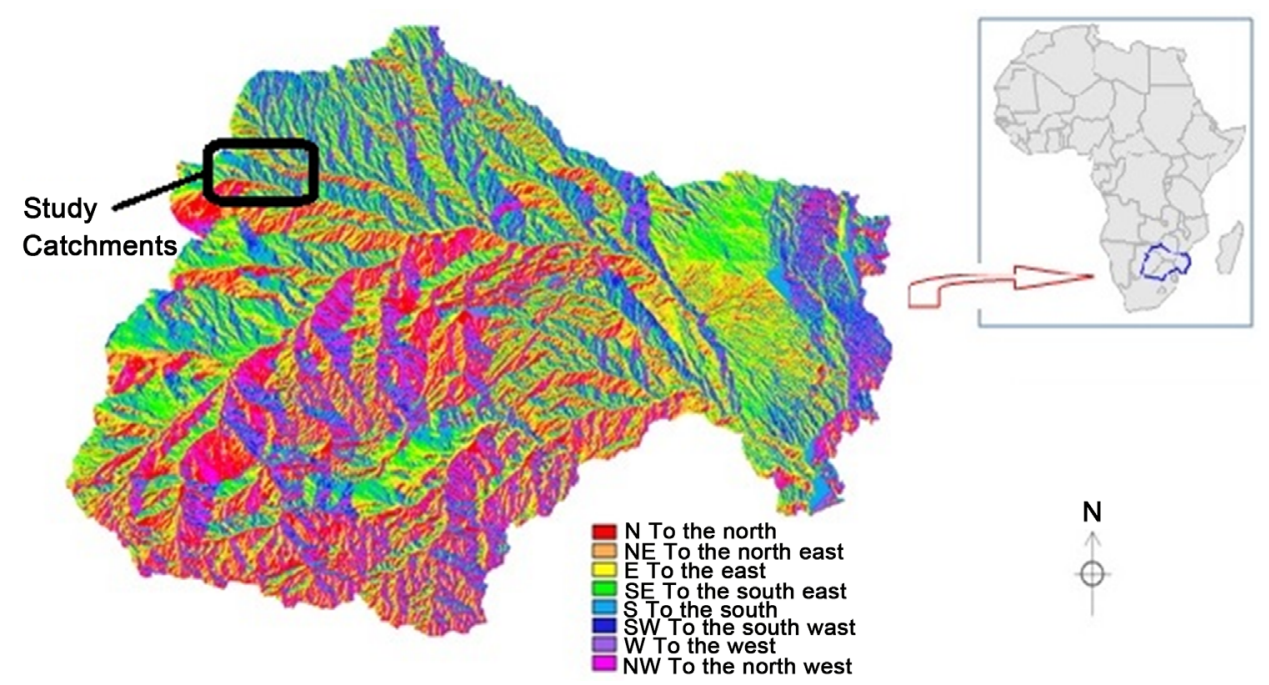

Figure 1. Location map of the study catchments and flow direction map of the Limpopo basin.

Table 2. Study catchment characteristics.

\begin{tabular}{|c|c|c|c|c|c|c|c|}
\hline \multirow{2}{*}{$\begin{array}{l}\text { Duration } \\
\text { (minutes) }\end{array}$} & \multicolumn{2}{|c|}{ Location } & \multirow{2}{*}{$\begin{array}{c}A \\
\left(\mathrm{~km}^{2}\right)\end{array}$} & \multirow{2}{*}{$\begin{array}{c}L \\
(\mathrm{~km})\end{array}$} & \multirow{2}{*}{$\begin{array}{c}S \\
(\%)\end{array}$} & \multirow{2}{*}{$\begin{array}{c}T c \\
\text { (hour) }\end{array}$} & \multirow{2}{*}{$\begin{array}{c}R \\
(\mathrm{~mm} / \mathrm{a})\end{array}$} \\
\hline & Longitude & Latitude & & & & & \\
\hline Nyamambisi & $27^{\circ} 14.52^{\prime}$ & $20^{\circ} 53.25^{\prime}$ & 155 & 19 & 0.33 & 5.5 & 450 \\
\hline Gatswane 1 & $27^{\circ} 40.76^{\prime}$ & $20^{\circ} 41.28^{\prime}$ & 101 & 25 & 0.75 & 5.5 & 440 \\
\hline Gatswane 2 & $27^{\circ} 40.89^{\prime}$ & $20^{\circ} 39.01^{\prime}$ & 111 & 31 & 0.79 & 6.0 & 440 \\
\hline Shashe & $27^{\circ} 17.60^{\prime}$ & $20^{\circ} 37.40^{\prime}$ & 117 & 19 & 0.70 & 4.0 & 447 \\
\hline
\end{tabular}

\section{Results and Discussion}

\subsection{The Design Strom and Flood Model}

Before the results discussion of the flood modeling results and associated risks in the design of drainage structures, we first illustrate the performance of the regional storm model.

Detail applicability of the storm IDF model written in computer spreadsheet program developed to optimize the three parameters of the proposed IDF model and to evaluate model performance and undertake error and necessary sensitivity analyses is provided in [21].

Using the observed rainfall data of Francistown which is close to the ungauged catchments we considered in this study, with mean annual rainfall $\mathrm{R}=458 \mathrm{~mm}$, the optimized parameter sets of the IDF curve using model form of Equation (5) are shown in Table 3.

As suggested by [22], a comprehensive assessment of model performance at least includes absolute error measure and relative error measure. In order to evaluate the performance of the model the following criteria were considered.

- Index of Volumetric Fit (IVF)-This is as a criterion representing the ratio of the observed to simulated volume of the storm under the observed and simulated IDF curves. 
Table 3. Parameters of the design storm model.

\begin{tabular}{ccc}
\hline Parameter & Range & Typical value \\
\hline$a$ & $1960-1980$ & 1970 \\
$b$ & $2900-3200$ & 3100 \\
$c$ & $18-21$ & 19 \\
\hline
\end{tabular}

- The model efficiency criteria $R^{2}$ [23] which is similar to the coefficient of determination, and

- The correlation coefficient, $r$, between the observed and simulated series of rainfall intensity for the durations considered $(5,10,20, \ldots, 100$ minutes).

Summary of results of application of the proposed storm model for Francistown in terms of the above model efficiency criteria is presented in Table 4. The values of $R^{2}$ range from $92.9 \%$ to $99.9 \%$, underlying the high percentage of the initial variance being accounted for by the proposed storm IDF model. Figure 2 shows the simulated IDF curve for the same station using the proposed model.

Extensive model calibration and validation tests with sensitivity analyses of the model are discussed in [21].

For the Nyamambisi catchment, rainfall intensities for selected durations and return periods simulated by the proposed regional storm design model, using a mean annual rainfall of $450 \mathrm{~mm}$ for the Nyamambisi watershed is shown in Figure 3. The corresponding 50 and 100 year design floods for the 4 case catchments based on the SCS CN and the empirical methods are summarized in Table 5.

\subsection{Risk Associated with Design Flood Estimates}

In the calculation of risk associated with the above design flood estimates, we adopted the General Extreme Value (GEV) as a regional frequency model. GEV was found to be a robust model for the Limpopo basin system through regional analysis [24]. Even though the L-Moments technique [25] of parameter estimation was used in [5] [24], in this study we used the method of moments to derive the higher moments of scale and shape parameters of this distribution. The location parameter that is associated with the mean of the flood series was estimated from the regional mean values scaled to catchment area of the respective watersheds considered in the study. With the help of the regional scale and shape parameters, and at site location parameter, the EV-1 reduced variate, and subsequently the recurrence interval $\mathrm{T}$, were computed for an assumed economic life of 50 years, in order to assess the hydrological risk involved $(0.1 \%, 15$ and $5 \%$ ) at each site (Table 6).

As it can be seen from Table 6, the computed flood quantities at the various risk levels, even as low as $0.1 \%$, are generally lower than those estimated by the CN method shown in Table 5. The overall design flood estimates adopted in the design of the drainage structure (in this case bridges and other structures such as dam spillways, etc) can fairly accommodate risks that might arise from flush floods that recur in the aforementioned design periods. 


\section{IDF Curve for Francistown}

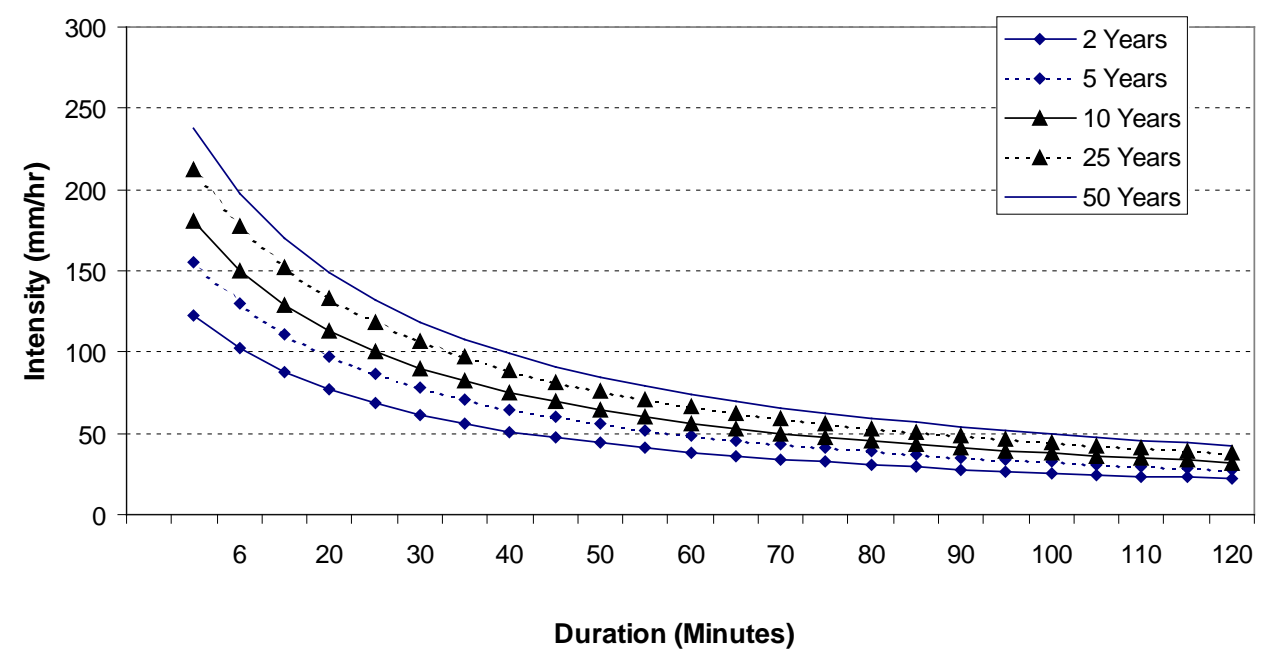

Figure 2. Simulated IDF curve for Francistown using the proposed model $(R=458 \mathrm{~mm} / \mathrm{a})$.

Table 4. Comparison of model performance results for Francistown.

\begin{tabular}{ccccc}
\hline & \multicolumn{4}{c}{ Return period (years) } \\
\cline { 2 - 5 } Duration (minutes) & 5 & 10 & 25 & 50 \\
\hline IVF & 1.03 & 0.95 & 0.87 & 0.83 \\
$R^{2}(\%)$ & 92.9 & 98.1 & 99.9 & 99.6 \\
$r$ & 0.995 & 0.996 & 0.997 & 0.992 \\
\hline
\end{tabular}

Table 5. Estimated 50 and 100 year design floods using the $\mathrm{CN}$ and empirical methods.

\begin{tabular}{ccccc}
\hline & \multicolumn{2}{c}{ CN method } & \multicolumn{2}{c}{ Empirical method } \\
\cline { 2 - 4 } Catchment & 50 years & 100 years & 50 years & 100 years \\
\hline Nyamambisi & 167 & 186 & 230 & 279 \\
Gatswane 1 & 224 & 248 & 210 & 289 \\
Gatswane 2 & 286 & 318 & 200 & 280 \\
Shashe & 350 & 388 & 222 & 302 \\
\hline
\end{tabular}

Table 6. Flood estimates $\left(\mathrm{m}^{3} / \mathrm{s}\right)$ and risk levels in four catchments in the Limpopo river basin.

\begin{tabular}{cccc}
\hline & \multicolumn{3}{c}{ Hydrological risk level } \\
\cline { 2 - 4 } Catchment & $0.1 \%$ & $1.0 \%$ & $5.0 \%$ \\
\hline Nyamambisi & 167 & 186 & 230 \\
Gatswane 1 & 224 & 248 & 210 \\
Gatswane 2 & 286 & 318 & 200 \\
Shashe & 350 & 388 & 222 \\
\hline
\end{tabular}


IDF Curve - Nyamanbisi Watershed- MAP $450 \mathrm{~mm} / \mathrm{a}$

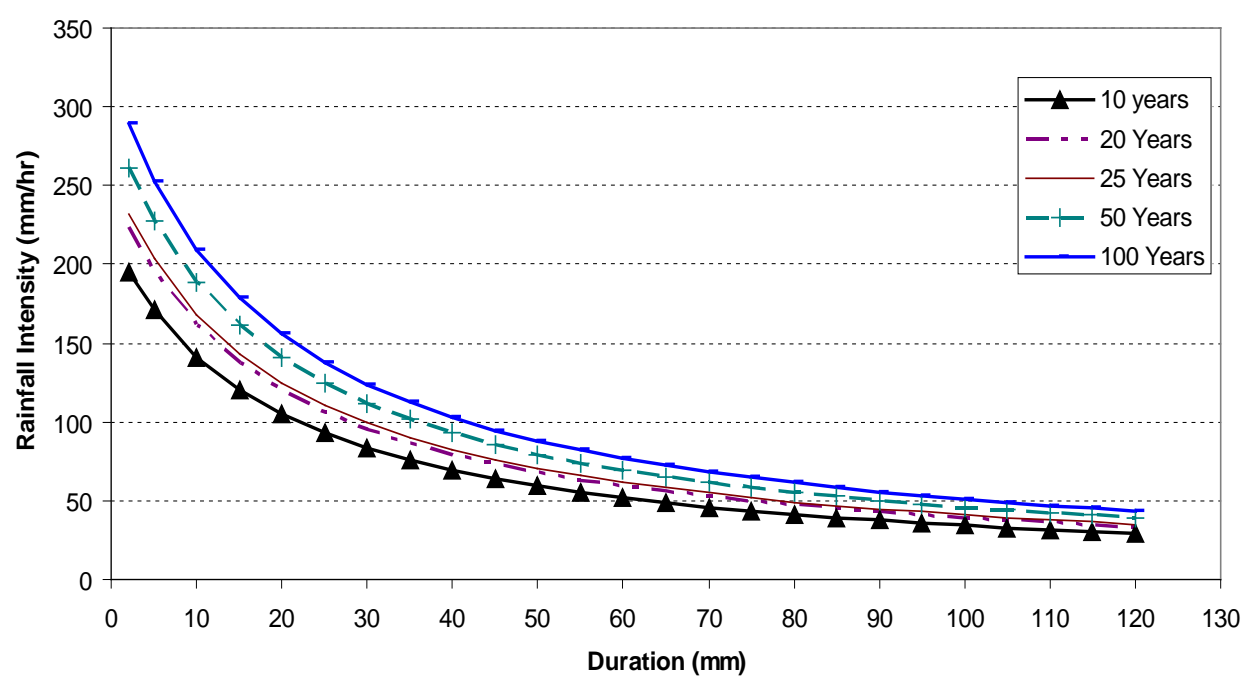

Figure 3. IDF curve derived for Nyamambisi watershed derived using model.

\section{Conclusions}

We have undertaken a risk assessment in design flood estimation using regional storm modeling approach. A generalized IDF model is proposed to produce the IDF relationships in Botswana. The performance of the model was judged against a number of model performance indices, which gave very high model efficiency $\left(R^{2}\right)$ that was well above $90 \%$, and a correlation coefficient $(r)$ and IVF, both close to unity. In similar studies [26], optimized values of model parameters were verified by the analysis of variance (ANOVA) and comparisons of model performances were analyzed by root mean square error (RMSE) and Nash-Sutcliffe efficiency (NSE) estimation.

In this study, the consistent agreement in quality and magnitude of rainfall intensity curves shows the acceptability for the use of the proposed design storm IntensityDuration-Frequency (IDF) model for the calculation of design flood estimates using an event based design flood modeling approach. This approach was also used to subsequently calculate the risk associated with the use of this design flood magnitudes for the design of drainage structures like culverts, bridges and other flood protection works, for any design period.

\section{Acknowledgements}

The authors wish to appreciate the support of the University of Botswana and Department of Metrological Services of the Botswana Government for encouraging this research directly or indirectly by providing the necessary information and support.

\section{References}

[1] Rahman, A., Weinmann, P.E., Hoang, T.M.T. and Laurenson, E.M. (2002) Monte Carlo Simulation of Flood Frequency Curves from Rainfall. Journal of Hydrology, 256, 196-210. https:/doi.org/10.1016/S0022-1694(01)00533-9 
[2] Adamowski, K. (2006) Scaling Model of Rainfall Intensity-Duration-Frequency Relationship. Hydrological Processes, 20, 3747-3757. https:/doi.org/10.1002/hyp.6386

[3] Bougadis, J. and Adamowski, K. (2006) Scaling Model of a Rainfall Intensity-DurationFrequency Relationship. Hydrological Processes, 20, 3747-3757.

https:/doi.org/10.1002/hyp.6386

[4] Willems, P. (2000) Compound Intensity/Duration/Frequency-Relationships of Extreme Precipitation for Two Seasons and Two Storm Types. Journal Hydrology, 233, 189-205. https:/doi.org/10.1016/S0022-1694(00)00233-X

[5] Wagesho, N. and Claire, M. (2016) Analysis of Rainfall Intensity-Duration-Frequency Relationship for Rwanda. Journal of Water Resource and Protection, 8, 706-723. https:/doi.org/10.4236/jwarp.2016.87058

[6] Yu, P.-S., Yang, T.-C. and Lin, C.-S. (2004) Regional Rainfall Intensity Formulas Based on Scaling Property of Rainfall. Journal of Hydrology, 295, 108-123. https:/doi.org/10.1016/j.jhydrol.2004.03.003

[7] Ben-Zvi, A. (2009) Rainfall Intensity-Duration-Frequency Relationships Derived from Large Partial Duration Series. Journal of Hydrology, 367, 104-114. https:/doi.org/10.1016/j.jhydrol.2009.01.007

[8] Bougadis, J., Cheng, L. and Agha Kouchak, A. (2014) Nonstationary Precipitation IntensityDuration-Frequency Curves for Infrastructure Design in a Changing Climate. Scientific Reports, 4, 7093. https:/doi.org/10.1038/srep07093

[9] De Paola, F., Giugni, M., Topa, M.E. and Bucchignani, E. (2014) Intensity Duration Frequency (IDF) Rainfall Curves, for Data Series and Climate Projection in Africa Cities. Springer Plus, 3, 133. https:/doi.org/10.1186/2193-1801-3-133

[10] Bhalotra, Y.P.R. (1987) Climate of Botswana, Part II, Elements of Climate. Republic of Botswana, Department of Meteorological Services, Gaborone.

[11] BRDM (1982) Botswana Road Design Manual. Republic of Botswana, Gaborone.

[12] Bhalotra, Y.P.R. (1985) Rainfall Maps of Botswana, Republic of Botswana. Department of Meteorological Services, Gaborone.

[13] Kuczera, G., Lambert, M., Heneker, T., Jennings, S., Frost, A. and Coombes, P. (2003) Joint Probability and Design Storms at the Crossroads, Keynote Paper. 28 th International Hydrology and Water Resources Symposium, Wollongong, 11-13 November 2003.

[14] Smith, A.A. and Lee, K.B. (1988) The Rational Method Revisited. Canadian Journal of Civil Engineering, 11, 854-862. https:/doi.org/10.1139/184-103

[15] US Soil Conservation Service (1985) National Engineering Handbook. Section 4, Hydrology Soil Conservation Service, USDA, Washington DC.

[16] USACE (1981) HEC-1, Flood Hydrograph Package US Army Corps of Engineers Hydrologic Engineering Center. User's Manual.

[17] Abbott, M.B., Bathurst, J.C., Cunge, J.A., O’Connell, P.E. and Rasmussen, J.L. (1986) An Introduction to the European Hydrology System SHE, 2, Structure of a Physically-Based, Distributed Modeling System. Journal of Hydrology, 87, 61-77. http://dx.doi.org/10.1016/0022-1694(86)90115-0

[18] US Environmental Protection Agency (1977) Stormwater Management Model. Version II, Report EPA-600/18-17-014, Washington DC.

[19] Kokkonen, T.S. and. Jakeman, A.J (2001) A Comparison of Metric and Conceptual Approaches in Rainfall-Runoff Modeling and Its Implications. Water Resources Research, 37, 2345-2352. http://dx.doi.org/10.1029/2001WR000299 
[20] Pitman, W.V. and Midgley, D.C. (1971) Amendments to Design Flood Manual HRU 4/69Flood Analysis of Peak Discharges. Report, No. 1/71, University of the Witswatersrand, Johannesburg.

[21] Alemaw, B.F. and Chaoka, T.R. (2009) Ageneralized Regional Design Storm Rainfall Model for Botswana. Botswana Journal of Technology, 18, 53-60.

[22] Legates, D.R and McCabe Jr., G.J. (1999) Evaluating the Use of Goodness-of-Fit Measures in Hydrologic and Hydroclimatic Model Validation. Water Resources Research, 35, 233241. http://dx.doi.org/10.1029/1998WR900018

[23] Nash, J.E. and Sutcliffe, J. (1970) River Flow Forecasting through Conceptual Models. Part I: A Discussion of Principles. Journal of Hydrology, 10, 282-290. http://dx.doi.org/10.1016/0022-1694(70)90255-6

[24] Parida, B.P., Kenabatho, P.K., Moalafhi, D.B., Kgaodi, D. and Odirile, P.T. (2005) Identifying a Common Distribution for Flood Estimation in Ungauged Catchments in Botswana. Botswana Journal of Technology, 14, 1-8.

[25] Hosking, J.R.M. and Wallis, J.R. (1993) Some Statistics Useful in Regional Frequency Analysis. Water Resources Research, 29, 271-281. http://dx.doi.org/10.1029/92WR01980

[26] Kar, K.K., Yang, S.K. and Lee, J.H. (2015) Assessing Unit Hydrograph Parameters and Peak Runoff Responses from Storm Rainfall Events: A Case Study in Hancheon Basin of Jeju Island. Journal of Environmental Science International, 24, 437-447. http://dx.doi.org/10.5322/JESI.2015.24.4.437

\section{Submit or recommend next manuscript to SCIRP and we will provide best service} for you:

Accepting pre-submission inquiries through Email, Facebook, LinkedIn, Twitter, etc.

A wide selection of journals (inclusive of 9 subjects, more than 200 journals)

Providing 24-hour high-quality service

User-friendly online submission system

Fair and swift peer-review system

Efficient typesetting and proofreading procedure

Display of the result of downloads and visits, as well as the number of cited articles

Maximum dissemination of your research work

Submit your manuscript at: http://papersubmission.scirp.org/

Or contact jwarp@scirp.org 